1994-3

\title{
Religious Devoutness, Impression Management, and Personality Functioning in College Students
}

P. Scott Richards

Brigham Young University - Provo, scott_richards@byu.edu

Follow this and additional works at: https://scholarsarchive.byu.edu/facpub

Part of the Student Counseling and Personnel Services Commons

\section{Original Publication Citation}

Richards, P.S. (1994). Religious devoutness and impression management in college students. Journal of Research in Personality, 28, 14-26.

\section{BYU ScholarsArchive Citation}

Richards, P. Scott, "Religious Devoutness, Impression Management, and Personality Functioning in College Students" (1994). Faculty Publications. 3864.

https://scholarsarchive.byu.edu/facpub/3864

This Peer-Reviewed Article is brought to you for free and open access by BYU ScholarsArchive. It has been accepted for inclusion in Faculty Publications by an authorized administrator of BYU ScholarsArchive. For more information, please contact ellen_amatangelo@byu.edu. 


\title{
Religious Devoutness, Impression Management, and Personality Functioning in College Students
}

\author{
P. SCOTT RichaRdS
}

\author{
Department of Educational Psychology, Brigham Young University
}

\begin{abstract}
Measures of religious devoutness, impression management, and personality adjustment were administered to 178 undergraduate students. Pearson correlations were computed. Greater devoutness (intrinsic religiousness) was associated with more religious and existential well-being, self-control, and social desirability, and with less self-monitoring. Consistent with previous research, the weak positive relation between religious devoutness and social desirability did not generalize to other impression management measures. Evidence which suggests that the relation between religious devoutness and social desirability may be an artifact of religious bias was discussed. (c) 1994 Academic Press, Inc.
\end{abstract}

During the past decade, several researchers have hypothesized that religiously devout persons are more likely than less religious persons to be overly concerned about maintaining socially desirable appearances, or to engage in impression management tactics (e.g., Batson \& Ventis, 1982; Batson, Naifeh, \& Pate, 1978; Ellis, 1985; Leak \& Fish, 1989). It is true that many Christian religions do place a very high value on moral and ethical conduct. In addition, the Biblical scripture, "Let your light so shine before men, that they may see your good works, and glorify your Father which is in heaven" (Matthew 5:16) is also invoked in some Christian denominations to emphasize the importance of believers projecting a positive, moral image to those with whom they associate. It seems possible that the expectation to live a moral life and to be a positive example to others could make religiously devout persons more invested

This project was partially supported by the Department of Psychology at the University of Minnesota-Duluth and the Department of Educational Psychology at Brigham Young University. I thank Steven Massey who helped collect the data and Rebecca Woolley who assisted with the literature search. Portions of this article were presented at the annual convention of the American Psychological Association in Toronto, Ontario, Canada, on August 21, 1993. Address correspondence and reprint requests to P. Scott Richards, Ph.D., 320-D MCKB, Educational Psychology, Brigham Young University, Provo, UT 84602.

$0092-6566 / 94 \$ 6.00$

Copyright 1994 by Acadernic Press, Inc

All rights of reproduction in any form reserved. 
than less religious persons in projecting favorable public impressionsbut no more likely to actually engage in these socially desirable behaviors.

If it were found that there is a positive association between religious devoutness and impression management this finding would have important implications for personality theory and for mental health professionals. An overly strong need to engage in impression management is viewed by many mental health professionals as a characteristic of people who are emotionally disturbed or maladjusted (e.g., Bednar, Wells, \& Peterson, 1989; Bergin, 1985; Jensen \& Bergin, 1988; Rogers, 1961). Persons who frequently engage in impression management tactics often do so to cover up low self-esteem and a flawed or threatened sense of self. Such persons are also often unable or unwilling to relate authentically and meaningfully to other people (Bednar et al., 1989; Crowne, 1979; Friedlander \& Schwartz, 1985; Rogers, 1961; Schlenker \& Leary, 1982). If there is a greater tendency for religiously devout persons to engage in impression management tactics, mental health professionals would need to be more alert to this possibility during their assessment and treatment of such persons.

There is in fact some empirical evidence which appears to support the "religious devoutness-impression management" hypothesis. Several researchers (e.g., Batson et al., 1978; Bolt \& Vermeulen, 1986; Pargament et al., 1987; Watson, Hood, Morris, \& Hall, 1984) have observed significant positive relations between the Social Desirability Index (SDI; Crowne \& Marlowe, 1960) and the Intrinsic scale (a measure of religious devoutness and commitment) of the Religious Orientation Scale (ROS; Allport \& Ross, 1967). Leak and Fish (1989) recently extended this research when they observed significant relations between intrinsic religiousness and the Balanced Inventory of Desirable Responding (BIDR, Version 3; Paulhus, 1984). Leak and Fish (1989) concluded that devoutly religious, intrinsic persons "have tendencies toward distortions in the way they see themselves . . . and in the way they intentionally present themselves to others ... the intrinsic may be overly concerned with appearances" (p, 358).

The religious devoutness-impression management hypothesis has been challenged (Donahue, 1988; Gorsuch, 1988; Watson, Morris, Foster, \& Hood, 1986). Five studies reported in Watson et al. (1986) have provided the most damaging evidence against the religious devoutness-impression management hypothesis. Watson and his colleagues (Watson et al., 1986) found that while devout (intrinsic) religiousness was positively associated with the SDI (Crowne \& Marlowe, 1960), it tended to be unrelated to several other impression management measures (i.e., self-consciousness, social anxiety, fear of negative evaluation, approval motivation, and a fake good scale). The Watson studies also called into question the validity 
of the SDI for religiously devout people by showing that a sizable number of items on the SDI have religious connotations and may therefore be biased for devoutly religious people.

While the studies by Watson and his colleagues raised serious doubts about the validity of the religious devoutness-impression management hypothesis, these studies were all done in one geographic area (Tennessee) by one group of researchers. Because of the importance of the Watson et al. (1986) studies with regards to the validity of the religious devoutnessimpression management hypothesis, there is a need to repeat and extend this research.

The purpose of the present article is to report the results of an empirical study I conducted which further examined the relation between religious devoutness and impression management. My study built upon Watson and his colleagues research in several ways. First, I used a measure of impression management, the Self-Monitoring Scale (Snyder, 1974; Gangestad and Snyder, 1985), which has not been utilized in previous studies addressing the impression management hypothesis. Second, I replicated Watson et al.'s research by using several measures of impression management which they used (social desirability, self-consciousness, and social anxiety measures). Third, I also used a measure of adaptive self-management tendencies, the Self-Control Schedule (Rosenbaum, 1980), in an effort to determine if religious devoutness is positively associated with adaptive self-management behavior, as opposed to less functional impression management tactics. Finally, my study was done in a different geographic region.

\section{METHOD}

\section{Subjects}

Subjects were 178 undergraduate students enrolled in several General Psychology classes during Fall Quarter, 1988, at the University of Minnesota-Duluth. One hundred and twenty of the subjects were females and 58 were males. The subjects ranged in age from 17 to 38 years and had a mean age of 19 years. One hundred and thirty-nine subjects were freshman, 36 were sophomores, and 3 were juniors. The average self-reported high school GPA of the subjects was 3.22 . One hundred and seventy-two (96.6\%) subjects were single.

Sixty-five subjects were Roman Catholic, 70 were Lutheran, 32 were of some other Protestant faith, 1 was Jewish, and 7 said they had no religious preference. One hundred and fifty-five subjects (87\%) indicated they were theistic (believe in a Supreme Being), 17 (9\%) said they were agnostic (not sure whether they believe in a Supreme Being), $5(3 \%)$ said they were atheistic (do not believe in a Supreme Being), and 1 subject did not respond to this item.

\section{Procedure}

Subjects were recruited by offering extra class credit for participation in the study. American Psychological Association ethical guidelines were followed in recruiting the subjects; 
participation was voluntary, and other alternatives for earning extra credit were available for those who did not wish to participate in the study.

When participants reported to the testing room, they were informed that the purpose of the study was to learn more about religiousness, personality, and social behavior. Subjects were given the packet of dependent measures which included: (a) a consent form, which stressed that participation was voluntary, assured subjects that their responses would be kept confidential, and asked the subjects to sign a release indicating that they were voluntarily participating in the study; (b) a demographic questionnaire which asked subjects to provide information such as sex, age, education level, and religious affiliation (if any); and (c) a number of dependent measures (described below) as well as two experimental measures which were not included in the present study.

\section{Measures}

The ROS (Allport \& Ross, 1967) was utilized as a measure of religious devoutness and commitment in the present study. Allport and Ross (1967) theorized that people may approach religion with an intrinsic $(I)$ or an extrinsic $(E)$ orientation and constructed the ROS to measure these orientations. They theorized that intrinsic people have internalized their religion and attempt to live it regardless of the external consequences. Extrinsic people, on the other hand, are more marginally committed and use their religion for their own ends. Research to date has provided general support for these conceptualizations (Donahue, 1985), although recent factor-analytic studies (Kirkpatrick, 1989) have revealed some psychometric deficiencies of the ROS (i.e., the $E$ items load on $E$ (social), $E$ (personal), and $E$ (residual) factors instead of just one $E$ factor as theorized). The ROS has also been criticized on theoretical grounds (Kirkpatrick \& Hood, 1990).

Nevertheless, even the critics agree that the $I$ scale of the ROS measures religious commitment and devoutness (e.g., Batson \& Ventis, 1982; Kirkpatrick \& Hood, 1990). In the present study, therefore, I was primarily interested in exploring the relations between intrinsicness $(I)$ and other personality variables. I also examined the relations between the $E, E_{w}, E_{p}$, and $E_{r}$ subscales of the ROS and the dependent measures in an effort to shed further light on the potential utility of the new $E$ subscales identified by Kirkpatrick (1989).

Several instruments were also administered which are thought to measure various aspects of impression management. The SDI (Crowne \& Marlowe, 1960) is a well known measure which was developed to assess individuals need for approval and concern about maintaining a socially desirable appearance.

The Self-Monitoring Scale (Snyder, 1974, p. 536) was constructed to measure the extent to which individuals "monitor (observe and control) their expressive behavior and selfpresentation." High self-monitoring individuals tend to be sensitive to social and interpersonal cues and are adept at modifying their self-presentation so that they fit in well regardless of the social situation. The Self-Monitoring Scale is reliable (Snyder, 1974), and research has been done which supports its construct validity (e.g., Snyder, 1979, Snyder \& Ickes, 1985). Recent psychometric work has resulted in a shortened, revised version of the SelfMonitoring Scale (Gangestad \& Snyder, 1985) which was used in the present study.

The Self-Consciousness Scale (Fenigstein, Scheier, \& Buss, 1975) is composed of three subscales: Public Self-Consciousness, Private Self-Consciousness, and Social Anxiety. Public Self-Consciousness measures the degree to which people direct their attention outward to their physical appearance and presentation style. People who are high in Public Self-Consciousness tend to be concerned about making a good public impression. Recent research has shown that the Public Self-Consciousness scale is composed of two factors: style consciousness and appearance consciousness (Burnkrant \& Page, 1984; Mittal \& Balasubramanian, 1987). Private Self-Consciousness measures the degree to which people direct their attention inward to their thoughts, moods, and motivations. The Private Self-Consciousness 
subscale is also composed of two factors: internal state of awareness and self-reflectiveness (Mittal \& Balasubramanian, 1987). The Social Anxiety subscale measures how shy, embarrassed, and nervous people feel in public situations. High scores on the Social Anxiety subscale suggest a lack of personal security and an undo concern about the evaluations of others. The Self-Consciousness Scale is reliable and there is evidence which supports its construct validity (e.g., Fenigstein et al., 1975).

$I$ also wished in Study 1 to explore the possibility that devoutly religious students have less favorable perceptions of their self-worth and personal well-being because such characteristics are often associated with an overconcern about impression management (Bednar et al., 1989; Crowne, 1979; Friedlander \& Schwartz, 1985; Schlenker \& Leary, 1982). Several instruments were therefore administered which measure various aspects of people's sense of self-worth and subjective well-being. The Rosenberg (1965) Self-Esteem Scale measures people's evaluative attitudes toward themselves or degree of self-esteem. Evidence supporting the validity and reliability of this measure has been reported (e.g., Rosenberg, 1965).

The Spiritual Well-Being Scale (SWBS; Ellison \& Paloutzian, 1978; Ellison, 1983a) is composed of existential (EWB) and religious well-being (RWB) subscales. While the Rosenberg Self-Esteem Scale focuses on peoples' self-esteem, the EWB subscale broadens the focus to measure peoples' sense of purpose and feelings of life satisfaction. The RWB subscale adds another dimension by measuring whether people perceive that God loves them and whether their relationship with God is fulfilling and meaningful. For religious people, feeling loved and accepted by God is an important indicator of their level of selfacceptance and well-being (Ellison, 1983b). Evidence supporting the reliability and validity of the SWBS has also been reported (e.g., Ellison, 1983a; Paloutzian \& Ellison, 1979).

The Self-Control Schedule (Rosenbaum, 1980) was developed to "assess the tendencies of individuals to apply self-management methods to the solution of common behavioral problems" (p. 110). The Self-Control Schedule measures an adaptive self-regulation tendency; that is, it does not suggest an undue concern about maintaining socially desirable appearances, rather it measure peoples' tendencies to engage in self-management strategies which are designed to help them cope with challenges. Evidence supporting the reliability and validity of the SCS has been reported (e.g., Richards, 1985; Rosenbaum, 1980).

A background information form, constructed by the researchers, was used to obtain demographic data such as gender, age, world view (i.e., theistic, agnostic, atheistic), and religious preference (e.g., Roman Catholic, Lutheran, Jewish) about the subjects.

\section{Analyses}

Pearson correlations were used to determine the relations between the $I, E, E$ (personal), $E$ (social), and $E$ (residual) subscales of the ROS and the various impression management, self-esteem, personal well-being, and self-control measures. Internal consistency reliabilities (Cronbach Alpha's) were also computed for all of the dependent measures.

\section{RESULTS}

Table 1 reports the Pearson correlations between the ROS subscales and the dependent measures, and the internal consistency reliabilities for the measures. Higher intrinsic $(l)$ scores were associated with more religious and existential well-being, self-control, and social desirability, and with less self-monitoring. There were no significant associations between extrinsicness $(E)$ and the dependent variables. Extrinsicness $(E)$ was unrelated to intrinsicness $(I) r=-.01,, p>.05$.

The newly identified extrinsic-social $\left(E_{\mathrm{s}}\right)$ and extrinsic-personal $\left(E_{\mathrm{p}}\right)$ 
TABLE 1

Pearson Correlations of the Religious Orientation Scale (ROS) with the Dependent Measures

\begin{tabular}{|c|c|c|c|c|c|c|}
\hline \multirow[b]{2}{*}{ Dependent measure } & \multirow[b]{2}{*}{ ICR } & \multicolumn{5}{|c|}{ ROS subscale } \\
\hline & & I & $\mathrm{E}$ & $E(s)$ & $E(p)$ & $E(r)$ \\
\hline Social Desirability Index & $(.78)$ & $.20^{* *}$ & -.01 & .12 & .04 & -.11 \\
\hline Self-Monitoring Scale & $(.60)$ & $-.19^{*}$ & .11 & -.03 & -.01 & $.20^{* *}$ \\
\hline Public Self-Consciousness & $(.82)$ & .05 & .01 & .03 & .02 & -.03 \\
\hline Style Consciousness & $(.75)$ & .05 & -.01 & .01 & -.01 & .01 \\
\hline Appearance Consciousness & $(.69)$ & .04 & .01 & .06 & .05 & -.05 \\
\hline Social Anxiety & $(.68)$ & .07 & .03 & .01 & .14 & -.05 \\
\hline Private Self-Consciousness & $(.59)$ & .08 & -.03 & -.05 & -.08 & .04 \\
\hline Self-Reflectiveness & $(.59)$ & .02 & .05 & .01 & .02 & .07 \\
\hline Internal Awareness & $(.56)$ & .10 & -.13 & -.07 & -.13 & -.07 \\
\hline Self-Esteem Scale & $(.88)$ & .04 & -.07 & -.08 & -.04 & -.03 \\
\hline Self-Control Schedule & $(.84)$ & $.23^{* *}$ & .02 & .09 & .05 & -.06 \\
\hline \multicolumn{7}{|l|}{ Spiritual Well-Being Scale } \\
\hline Religious Well-Being & $(.93)$ & $.74^{* * *}$ & .03 & $.31^{* *}$ & $.39^{* *}$ & $-.42^{* *}$ \\
\hline Existential Well-Being & $(.78)$ & $.19^{*}$ & .02 & .12 & .06 & -.09 \\
\hline
\end{tabular}

Note. I, intrinsic; E, extrinsic; E(s), extrinsic (social); E(p), extrinsic (personal); $E(r)$, extrinsic (residual). ICR, Internal Consistency (Cronbach Alpha) Reliability.

$$
\begin{aligned}
{ }^{*} p & <.05 \\
{ }^{* *} p & <.01 . \\
p & <.001 . N=178 .
\end{aligned}
$$


ROS subscales were also unrelated to the dependent variables, with the exception that both of these subscales were positively associated with religious well-being. The extrinsic-residual or "unimportance of religion" $\left(E_{\mathrm{r}}\right)$ subscale (Kirkpatrick, 1989) was positively associated with self-monitoring and negatively associated with religious well-being. Both $E_{\mathrm{s}}$ ( $r=$ $.28, p<.01)$ and $E_{\mathrm{p}}(r=.27, p<.01)$ were positively associated, while $E_{\mathrm{r}}(r=-.38, p<.01)$ was negatively associated with intrinsicness $(I)$. The reliability of the intrinsic subscale of the ROS was .78. The reliabilities of the extrinsic (full), extrinsic (social), extrinsic (personal), and extrinsic (residual) subscales of the ROS were respectively .56, .55, .51, and .48.

\section{DISCUSSION}

The finding that there was a positive relation between intrinsicness ( $I$ ) and the SDI (Crowne \& Marlowe, 1960) is consistent with previous research (e.g., Batson et al., 1978; Bolt \& Vermeulen, 1986; Pargament et al., 1987; Watson et al., 1984) and appears to indicate that there is a weak tendency for more religiously devout, intrinsic persons to have a stronger need for approval and concern about maintaining socially desirable appearances. However, consistent with Watson et al.'s (1986) research, in my study support for the religious devoutness-impression management hypothesis did not generalize to other impression management measures.

My finding that the relations between intrinsicness and the self-consciousness and social anxiety scales were nonsignificant is consistent with Watson et al.'s (1986) Study 1 and Study 2 and indicates that more religiously devout persons have no more of a tendency to be socially anxious or self-conscious about their public impressions or private thoughts or moods. My finding that there was a negative relation between intrinsicness and the Self-Monitoring Scale (Snyder, 1974) also conflicts with the religious devoutness-impression management hypothesis because it suggests there is a weak tendency for more devoutly religious persons to be less concerned about modifying their self-presentation for the sake of fitting into social situations. Low self-monitors tend to be congruent; that is, the correspondence between their private attitudes and public behavior tends to be high (Snyder, 1979; Snyder \& Ickes, 1985). The negative relation between intrinsicness and self-monitoring suggests, therefore, that there is actually a weak tendency for religiously devout persons to manifest more congruence between their private attitudes and public behavior compared to less religious persons.

The relations between intrinsic religiousness and the adjustment and well-being variables also failed to support the religious devoutness-impression management hypothesis. If the devoutness-impression management hypothesis is correct, we would expect intrinsic religiousness to be as- 
sociated with lower self-esteem and poorer well-being because such characteristics tend to be associated with an overconcern about impression management (Bednar et al., 1989; Crowne, 1979; Friedlander \& Schwartz, 1985; Schlenker \& Leary, 1982). However, the finding in the present study that intrinsicness was uncorrelated with self-esteem runs contrary to this notion and suggests that the religiously devout persons were no more likely than less religious persons to have an underlying negative sense of self-esteem.

The finding that intrinsicness was positively associated with existential and religious well-being suggests the religiously devout persons tended to feel more satisfaction and purpose in their lives and to feel more loved and valued by God compared to the less religious persons. In addition, consistent with previous research (Richards, 1985), the finding that there was a positive association between intrinsicness and self-control suggests there is a weak tendency for more religiously devout persons to more often engage in self-management strategies and to feel a greater sense of personal control and self-efficacy when faced with behavioral or emotional challenges.

\section{The Religious Bias Hypothesis}

Why has the positive relation so often observed between the SDI and religious devoutness (intrinsicness) not generalized consistently to other impression management measures? Currently, it appears that the most plausible explanation that has been offered is that the SDI is biased or invalid for religiously devout persons (Donahue, 1988; Morris, Hood, \& Watson, 1989; Pearson \& Francis, 1989; Watson et al., 1986). Donahue (1988) clearly articulated the crux of the religious bias hypothesis when he stated, "The SDI measures social desirability by having the respondent indicate whether it is true or false that they consistently do or do not perform certain acts. If the acts included in the list are, a priori, more likely to be performed by religious people than by nonreligious, then that particular measure of social desirability is biased against religious respondents" (Donahue, 1988, p. 5).

There are several other impression management measures like the SDI which assume subjects are lying if they indicate they engage (or do not engage) in certain behaviors, including the lie scales of the Eysenck Personality Questionaire (EPQ) and Junior Eysenck Personality Questionaire, the Edwards Social Desirability Scale, and the BIDR. Interestingly, almost all of the other positive relations reported between religiousness and impression management have been observed on the EPQ, JEPQ, and BIDR (Leak \& Fish, 1989; Pearson \& Francis, 1989); measures which are vulnerable to the same bias that Donahue (1988) argued exists in the SDI. 
Several studies have been conducted which confirm that a large number of items on the SDI describe behaviors and values which are in harmony (or conflict) with the beliefs of religiously devout people (Morris et al., 1989; Watson et al., 1986) and are "precisely the sort of statements that a religiously committed person could make (or deny) in good conscience" (Donahue, 1988, p. 5). In the present study, in a post-hoc analysis recommended by a reviewer, I tested the hypothesis that the 12 SDI items which Watson et al., (1986) found have religious connotations for Protestants and Catholics would correlate more highly with intrinsicness than would the remaining 21 SDI items. I computed a subscale score for the 12 religiously relevant SDI items and a subscale score for the remaining $21 \mathrm{SDI}$ items. The correlation between the religiously relevant (12 item) SDI subscale and the intrinsic scale of the ROS was $.24, p<.01$ (the corrected for attenuation correlation was .34). The correlation between the religiously less relevant $(21 \mathrm{item}$ ) SDI subscale was $.14, p>.05$ (the corrected for attenuation correlation was .19). Thus, this analysis confirmed that intrinsic religiousness is more strongly associated with SDI items which have religious connotations than with other SDI items. It may be that intrinsically religious persons more strongly endorse the religiously relevant SDI items because, due to their religious values, they actually do engage in these behaviors more (or less) often.

There is, in fact, evidence that religious persons who score higher on the SDI and the lie scales of the EPQ and JEPQ are not bigger liars, but are actually more likely to tell the truth and to present an honest picture of themselves than are persons who obtain low scores on these measures (e.g., McCrae \& Costa, 1983, 1985; Morris et al., 1989; Pearson \& Francis, 1989). Pearson and Francis (1989) concluded that "religious adolescents are generally better behaved ... their high score on the lie scale [of the EPQ] is the result of their truthful reporting of their better behavior" (p. 1045). Morris and his colleagues concluded that for intrinsic religious students, "elevated Marlowe-Crowne [SDI] values may indicate that they are reporting something that is factually true-not that they want to appear socially desirable, but rather that they are more desirable socially" (Morris et al., 1989, p. 84). It appears, therefore, that religiously devout persons may often be telling the truth when they report that they engage in a higher frequency of socially desirable behaviors (Donahue, 1988; Morris et al., 1989; Pearson \& Francis, 1989), but their responses to the SDI and related measures such as the EPQ, JEPQ, and BIDR are scored as if they were lying.

\section{The Extrinsic Subscales}

The positive relations observed between the $E_{\mathrm{s}}$ and $E_{\mathrm{p}}$ subscales of the ROS and intrinsicness (I) and religious well-being is consistent with other 
recent research which has found that the $E_{\mathrm{s}}$ and $E_{\mathrm{p}}$ subscales tend to correlate positively with other measures of religious belief (Watson, Morris, \& Hood, 1990), while the full-length extrinsic $(E)$ scale tends to be unrelated or negatively related to such measures (Donahue, 1985; Watson et al., 1990). The failure of the full-length extrinsic $(E)$ scale to correlate positively with other religious variables appears to be due to the "residual" or "unimportance of religion" items on the $E$ scale which confound or mask these relations (Watson et al., 1990). Dividing the full-length extrinsic $(E)$ scale into the $E_{\mathrm{s}}, E_{\mathrm{p}}$, and $E_{\mathrm{r}}$ subscales clarified things in the present study and revealed that the extrinsic (social) and extrinsic (personal) religious motivations were positively associated, while the extrinsic (residual or unimportance of religion) scale was negatively associated with intrinsicness and religious well-being.

Consistent with previous research (Watson et al., 1990), my finding that the $E_{\mathrm{s}}$ and $E_{\mathrm{p}}$ subscales were not significantly related to existential wellbeing, self-esteem, or self-control suggests that the extrinsic (social and personal) religious orientations are not positively associated with personality adjustment and well-being. My study also suggests that the extrinsic (social) and (personal) orientations are not associated with the need to engage in impression management tactics. Interesting, those who regard religion as less important in their lives (i.e., those who more strongly endorse the extrinsic-residual items) were more likely to self-monitor their public self-presentation.

\section{Limitations}

Several limitations of this study should be kept in mind. Subjects were not selected randomly and so caution in generalizing the findings beyond the present sample of college freshman and sophomores is necessary. This study also needs to be repeated with persons of other religious faiths. The study was correlational in nature and so conclusions about causation are not possible. Finally, all of the conclusions regarding the $E, E_{\mathrm{p}}, E_{\mathrm{s}}$, and $E_{\mathrm{r}}$ subscales of the ROS should be viewed tentatively. Due to the shortness of these scales (three items on the $E_{\mathrm{p}}$ and $E_{\mathrm{s}}$ scales and five items on the $E_{r}$ scale) and their subsequent low reliabilities, relations between them and other measures have undoubtedly been underestimated. Expanded versions of the $E_{\mathrm{p}}, E_{\mathrm{s}}$, and $E_{\mathrm{r}}$ subscales need to be developed if we are to better understand these religious orientations.

\section{Conclusions}

While a number of studies have observed small, positive relations between religious devoutness (intrinsicness) and the SDI (Crowne \& Marlowe, 1960), this finding has to date not generalized consistently to other measures of impression management (Watson et al., 1986). The present 
study confirmed and extended this finding by showing that religious devoutness was unrelated to self-consciousness and social anxiety and negatively related to self-monitoring in a sample of college students in northern Minnesota. The positive relations which have been observed between religious devoutness and the SDI may, therefore, be an artifact of religiously biased items in the SDI.

Consistent with other recent studies (e.g., Bergin, Masters, \& Richards, 1987; Bergin, Stinchfield, Gaskin, Masters, \& Sullivan, 1988; Hathaway \& Pargament, 1990; Richards, 1991), my data also provided some additional evidence that religious devoutness is weakly, but positively associated with some indicators of personality adjustment and well-being (i.e., self-control and existential well-being). Thus, because there is currently little empirical justification for assuming that religiously devout persons have a stronger need to engage in impression management tactics than do less religious persons, mental health professionals should be careful to avoid stereotyping religiously devout clients as less congruent or genuine.

\section{REFERENCES}

Allport, G. W., \& Ross, J. M. (1967). Personal religious orientation and prejudice. Journal of Personality and Social Psychology, 5, 432-443.

Batson, C. D., Naifeh, S. J., \& Pate, S. (1978). Social desirability, religious orientation, and racial prejudice. Journal for the Scientific Study of Religion, 17, 31-41.

Batson, C. D., \& Ventis, W. L. (1982). The religious experience: A social-psychological perspective. New York: Oxford.

Bednar, R. L., Wells, M. G., \& Peterson, S. R. (1989). Self-esteem: Paradoxes and innovations in clinical theory and practice. Washington, DC: American Psychological Association.

Bergin, A. E. (1985). Proposed values for guiding and evaluating counseling and psychotherapy. Counseling and Values, 29, 99-116.

Bergin, A. E., Masters, K. S., \& Richards, P. S. (1987). Religiousness and mental health reconsidered: A study of an intrinsically religious sample. Journal of Counseling $P_{s y \text { - }}$ chology, 34, 197-204.

Bergin, A. E., Stinchfield, R. D., Gaskin, T. A., Masters, K. S., \& Sullivan, C. E. (1988). Religious lifestyles and mental health: An exploratory study. Journal of Counseling Psychology, 35, 91-98.

Bolt, M., \& Vermeulen, D. (1986, August). Religious orientation and social compassion. Paper presented at the annual convention of the American Psychological Association, Washington, DC.

Burnkrant, R. E., \& Page, T. J., Jr. (1984). A modification of the Fenigstein, Scheier, and Buss Self-Consciousness scales. Journal of Personality Assessment, 48, 629-637.

Crowne, D. P. (1979). The experimental study of personality. Hillsdale, NJ: Erlbaum Associates.

Crowne, D. P., \& Marlowe, D. (1960). A new scale of social desirability independent of psychopathology. Journal of Consulting Psychology, 4, 349-354.

Donahue, M. J. (1985). Intrinsic and extrinsic religiousness: Review and meta-analysis. Journal of Personality and Social Psychology, 48, 400-419. 
Donahue, M. J. (1988, November). Religion and personality: Investigations of related dimensions. Invited address presented at the International Congress of Christian Counseling, Atlanta.

Ellis, A. (1985, August). Some religious beliefs help produce emotional disturbance and need investigation. Paper presented at the annual convention of the American Psychological Association, Los Angeles.

Ellison, C. W. (1983a). Spiritual well-being: Conceptualization and measurement. Journal of Psychology and Theology, 11, 330-340.

Ellison, C. W. (1983b). Your better self: Christianity, psychology, and self-esteem. San Francisco: Harper \& Row.

Ellison, C. W., \& Paloutzian, R. F. (1978, August). Assessing quality of life: Spiritual wellbeing. Paper presented at the annual meeting of the American Psychological Association, Toronto.

Fenigstein, A., Scheier, M. F., \& Buss, A. H. (1975). Public and private self-consciousness: Assessment and theory. Journal of Consulting and Clinical Psychology, 43, 522-527.

Friedlander, M. L., \& Schwartz, G. S. (1985). Toward a theory of strategic self-presentation in counseling and psychotherapy. Journal of Counseling Psychology, 32, 483-501.

Gangestad, S., \& Snyder, M. (1985). "To carve nature at its joints": On the existence of discrete classes in personality. Psychological Review, 92, 317-349.

Gorsuch, R. L. (1988). Psychology of religion. Annual Review of Psychology, 39, 201-221.

Hathaway, W. L., \& Pargament, K. I. (1990). Intrinsic religiousness, religious coping, and psychosocial competence: A covariance structure analysis. Journal for the Scientific Study of Religion, 29, 423-441.

Jensen, J. P., \& Bergin, A. E. (1988). Mental health values of professional therapists: A national interdisiplinary survery. Professional Psychology: Research and Practice, 19, 290-297.

Kirkpatrick, L. A. (1989). A psychometric analysis of the Allport-Ross and Feagin measures of intrinsic-extrinsic religious orientation. Research in the Social Scientific Study of Religion, 1, 1-31.

Kirkpatrick, L. A., \& Hood, R. W., Jr. (1990). Intrinsic-extrinsic religious orientation: The boon or bane of contemporary psychology of religion? Journal for the Scientific Study of Religion, 29, 442-462.

Leak, G. K., \& Fish, S. (1989). Religious orientation, impression management, and selfdeception: Toward a clarification of the link between religiosity and social desirability. Journal for the Scientific Study of Religion, 28, 355-359.

McCrae, R. R., \& Costa, P. T., Jr. (1983). Social desirability scales: More substance than style. Journal of Consulting and Clinical Psychology, 51, 882-888.

McCrae, R. R., \& Costa, P. T., Jr. (1985). Comparison of EPI and psychoticism scales with measures of the five-factor model of personality. Personality and Individual Differences, 6, 587-597.

Mittal, B., \& Balasubramanian, S. K. (1987). Testing the dimensionality of the self-consciousness scales. Journal of Personality Assessment, 51, 53-68.

Morris, R. J., Hood, R. W., Jr., \& Watson, P. J. (1989). A second look at religious orientation, social desirability, and prejudice. Bulletin of the Psychonomic Society, 27, $81-84$.

Paloutzian, R. F., \& Ellison, C. W. (1979). Developing a measure of spiritual well-being. In R. F. Paloutzian (Chair), Spiritual well-being, loneliness, and perceived quality of life. Symposium presented at the annual meeting of the American Psychological Association, Toronto.

Pargament, K. L., et al. (1987). Indiscriminate proreligiousness: Conceptualization and measurement. Journal for the Scientific Study of Religion, 26, 182-200. 
Paulhus, D. L. (1984). Two-component models of socially desirable responding. Journal of Personality and Social Psychology, 46, 598-609.

Pearson, P. R., \& Francis, L. J. (1989). The dual nature of the Eysenckian lie scales: Are religious adolescents more truthful? Personality and Individual Differences, 10, 10411048.

Richards, P. S. (1985). Construct validation of the self-control schedule. Journal of Research in Personality, 19, 208-218.

Richards, P. S. (1991). Religious devoutness in college students: Relations with emotional adjustment and psychological separation from parents. Journal of Counseling Psychology, 38, 189-196.

Rogers, C. R. (1961). On becoming a person. Boston: Houghton Mifflin.

Rosenbaum, M. (1980). A schedule for assessing self-control behaviors: Preliminary findings. Behavior Therapy, 11, 109-121.

Rosenberg, M. (1965). Society and the adolescent self-image. Princeton, NJ: Princeton Univ. Press.

Schlenker, B. R., \& Leary, M. R. (1982). Social anxiety and self-presentation: A conceptualization and model. Psychological Bulletin, 92, 641-669.

Snyder, M. (1974). Self-monitoring of expressive behavior. Journal of Personality and Social Psychology, 30, 526-537.

Snyder, M. (1979). Self-monitoring processes. Advances in Experimental Social Psychology, $12,85-128$.

Snyder, M., \& Ickes, W. (1985). Personality and social behavior. In G. Lindzey \& E. Aronson (Eds.), Handbook of social psychology (3rd ed., pp. 883-948). New York, NY: Random House.

Watson, P. J., Hood, R. W., Jr., Morris, R. J., \& Hall, J. R. (1984). Empathy, religious orientation, and social desirability. The Journal of Psychology, 117, 211-216.

Watson, P. J., Morris, R. J., Foster, J. E., \& Hood, R. W. (1986). Religiosity and social desirability. Journal for the Scientific Study of Religion, 25, 215-232.

Watson, P. J., Morris, R. J., \& Hood, R. W., Jr. (1990). Extrinsic scale factors: Correlations and construction of religious orientation types. Journal of Psychology and Christianity, 9, 35-46. 